\title{
Vicent Salvador
}

\author{
Will of a Rich MaN \\ I shall leave my friends a clock \\ to pace the passage of hatred. \\ I shall leave them a needle to sew assertions. \\ I shall leave them a silence turned to paper. \\ I shall wish them the most savory journey.
}

\section{MARCH WIND}

The March wind howls like a man living under the penalty of death. We know, April tiptoes in, hiding knives beneath its wings and promising rain. The prayer had been a groan growing from the folds of this waste land. The foot enters a new realm: how I am thirsty for barefoot Aprils! Mine is a faceless April, just living rock and the fury of the path. Something is for certain: tomorrow is Saturday and we need to put our lives on the salt market. The risk is the highest ever taken by the people of this neighborhood, of this slum, kneaded with lilies and mud, flourpaste and dung. Mine is a faceless April, but I sniff its hair and feel in my veins its approaching drums, as once we put our ears to the rail and our hearts shook in warpaint.

\section{Nobody's Answering Machine}

This is Nobody's answering machine. I am His delegated voice panting in the dark, the alien voice that reasons and complains when you rub my chest with greenleaf hands.

Now listen carefully to these words which die on the shore. Please say your name, placing it, like a spell, on the gentle wave that will lick your foot. Say the year you are reporting from and 
where in the galaxy, whether you are spring or winter, whether your body blooms or ages, or is sheer mind grooved by the paths of knowledge. Mention your sex, adding plentiful details, and any other coordinates that may help locate you in the sideral magma you depart from.

Nobody's words will be yours, and the inner walls of the cave will resound with strokes, the answer to a voice in the void, not resting until heard, remaining forever said, proud words spinning on the reel of a poet.

\section{How Odd ThIS LANDSCAPE}

How odd this landscape for death, where our memoryknives on firedictates with which fingernails by which murky waters we once made love.

Lunar trees defeated among the rocks, too exhausted for love, and fearing the woodcutterwe hear bodies creak by night. 